\title{
The Relationship of Amount of Pleural Fluid and Time of Pleurodesis with the Results of Pleurodesis in Malignant Pleural Effusions
}

\author{
Yusup Subagio Sutanto, Indarto Sigit, Hendra Kurniawan
}

Department of Pulmonology and Respiratory Medicine, Faculty of Medicine/ Universitas Sebelas Maret, Dr. Moewardi Hospital, Surakarta

\section{ABSTRACT}

Background: Pleural effusion can be an early sign of lung cancer in more than $25 \%$ of cases. Lung cancer is the most common cause of malignant pleural effusion (MPE). Pleurodesis is performed when the amount of pleural fluid is $<150 \mathrm{ml} /$ day, but it is difficult as its productive nature. This study aimed to find the right time to perform pleurodesis on patients with MPE, which is expected to achieve optimal results.

Subjects and Method: This was a cross-sectional study conducted at Dr. Moewardi Hospital, Surakarta, Central Java, from June to July 2020. The study subjects were 17 patients with malignant pleural effusion (MPE) diagnosed with lung cancer who underwent water seal drainage (WSD) and indicated for pleurodesis. The dependent variable was the success of the pleurodesis procedure. The independent variables were the amount of evacuated pleural fluid and the time of pleurodesis performed. The study instruments were diagnosis of lung cancer with anatomic pathology, measurement of the amount of pleural fluid, and posteroanterior chest X-ray evaluating the success of pleurodesis. The data were analyzed using Spearman correlation, ANOVA to determine the differences in the amount of pleural fluid at the first, second, and third hours, and continued with post hoc LSD analysis using SPSS 21.

Results: The pleurodesis success rate had positive correlation with the amount of pleural fluid ( $\mathrm{r}=0.24 ; \mathrm{p}=0.345)$ and the time of pleurodesis performed at the first hour $(\mathrm{r}=0.10 ; \mathrm{p}=$ $0.701)$, second hour $(\mathrm{r}=0.03 ; \mathrm{p}=0.921)$, and third hour $(\mathrm{r}=0.41 ; \mathrm{p}=0.106)$. Pleurodesis performed at the second hour had the lowest amount of pleural fluid (Mean=84.66; $\mathrm{SD}=$ 38.88 ), followed by third hour (Mean= 110.77; $\mathrm{SD}=65.57)$, and first hour (Mean=111.22; $\mathrm{SD}=$ 57.83 ), but the differences were not statistically significant $(\mathrm{p}=0.285)$.

Conclusion: The pleurodesis success rate has a positive correlation with the amount of pleural fluid and the time of pleurodesis, but it was not statistically significant. There is no significant difference in the amount of pleural fluid evacuated at the three different times of pleurodesis. The least amount of pleural fluid obtains at the second hour (14.00-22.00).

Keywords: malignant pleural effusion, amount of pleural fluid, pleurodesis, pleurodesis time

\section{Correspondence:}

Yusup Subagio Sutanto. Department of Pulmonology and Respiratory Medicine, Faculty of Medicine Universitas Sebelas Maret, Dr. Moewardi Hospital, Surakarta. Jl. Kolonel Sutarto 132, Surakarta 57126, Central Java. Email: dr_yusupsubagio@yahoo.com. Mobile: +62811284165 .

\section{Cite this as:}

Sutanto YS, Sigit I, Kurniawan H (2020). The Relationship of Amount of Pleural Fluid and Time of Pleurodesis with the Results of Pleurodesis in Malignant Pleural Effusions. Indones J Med. 05(04): 337-342. https://doi.org/10.26911/theijmed.2020.05.04.09.

c) (i) (-) Indonesian Journal of Medicine is licensed under a Creative Commons

Attribution-Non Commercial-Share Alike 4.o International License.

\section{BACKGROUND}

Pleural effusion results from the accumulation of abnormal fluid in the pleural cavity, caused by several conditions, including congestive heart failure, pneumonia, and malignancy (El-Kolaly et al., 2016). Pleural 
effusion can be an early sign of lung cancer in more than $25 \%$ of cases. Lung cancer itself is also the most common cause of malignant pleural effusions (MPE) (Liu et al., 2015).

Patients diagnosed with malignancy can be occurred pleural effusion, but in some cases cannot find malignant cells in the fluid or pleural tissue. Pleural effusion associated with the effects of primary tumors or complications of primary tumor therapy is called a para-malignant pleural effusion (Jantz and Antony, 2008; Shafiq et al., 2015). The main goals of MPE management are fluid evacuation and prevention of recurrent pleural effusions by performing pleurodesis. Pleurodesis is a procedure to obliterate the pleural space to prevent fluid accumulation (Liu et al., 2015).

Pleurodesis may prevent the repeated hospitalization of thoracocentesis, especially in patients with metastatic cancer with a long-life expectancy (Rafei et al., 2015; Burgers et al., 2008; Krochmal et al., 2016). Pleurodesis is performed when the lungs are fully expanded visualized from chest Xrays, and fluid production is $<150$ cc per day. But it is not easy to obtain this amount of fluid due to its productive nature. Recent studies had shown that pleurodesis could be performed as soon as the lungs expand after being released from the output chest tube (Jantz and Antony, 2008; Roberts et al., 2010).

The indications for successful pleurodesis are: (1) Complete response, which is free of symptoms associated with effusion, with no fluid accumulation on chest X-rays until death; (2) Partial response is reduced breathlessness due to effusion, with only partial fluid re-accumulation (radiographic evidence of $50 \%$ initial fluid), and requires thoracocentesis therapy during follow-up; and (3) Failed pleurodesis, is a failure as defined above (Roberts et al., 2010).
There have been no previous studies examining the relationship of the amount of pleural fluid production and the time of pleurodesis on the success rate of pleurodesis in patients with malignant pleural effusion with lung cancer, so researchers were interested in examining this.

\section{SUBJECTS AND METHOD}

\section{Study Design}

A cross-sectional study was conducted at Dr. Moewardi Hospital, Surakarta, Central Java, from June to July 2020.

\section{Population dan Sample}

The study subjects were 17 patients diagnosed with malignant pleural effusion due to lung cancer who were treated with water seal drainage (WSD) and indicated pleurodesis.

Inclusion criteria were patients diagnosed with clinically malignant pleural effusion due to lung cancer, willing to participate in the study, and signed a consent form. Exclusion criteria were patients with a history of previous pleurodesis, patients with pleural effusions due to cancer metastases from other than lung. Discontinuous criteria are if the patient resigns or dies.

\section{Study Variables}

The dependent variable was the success of the pleurodesis procedure in patients with malignant pleural effusion due to lung cancer. The independent variables were the amount of evacuated pleural fluid and the time of pleurodesis performed.

\section{Operational Definition of Variables} The amount of pleural fluid was defined as a condition characterized by the accumulation of pleural fluid between the visceral pleura and the parietal pleura.

Pleurodesis time was defined as the time determined to carry out pleurodesis in the patient. The patient inserted WSD thoracic catheter with maximal pleural fluid evacuation was observed in three different times 
and recorded the amount of pleural fluid production. The division of three observation times were the first observation (hour I) at $07.00-14.00$, second observation (hour II) between $14.00-22.00$, and the third observation (hour III) at 22.00 07.00.

The success rate of pleurodesis was defined as: (1) Complete response that is free of symptoms associated with effusion, with no fluid reaccumulating on chest X-ray until death; (2) Partial response, i.e., reduced breathlessness due to effusion, with only partial fluid reaccumulating (radiographic evidence of $50 \%$ initial fluid), and still requiring thoracocentesis therapy during follow-up; and (3) Failed pleurodesis, is a failure to reach the response defined above. Pleurodesis was carried out on observations where the amount of pleural fluid production was the least and then the success rate was assessed.

\section{Study Instruments}

The study instruments were diagnosis of lung cancer with anatomic pathology, measurement of the amount of pleural fluid, and posteroanterior chest X-ray evaluating the success of pleurodesis.

\section{Data Analysis}

Data analysis was performed using SPSS 21. In univariate analysis, the characteristic sample was continuous data presented in the parameters $\mathrm{n}$, mean, standard deviation, minimum, and maximum. Categorical data were presented in frequency and percentages. Bivariate analysis was performed with Spearman correlation, ANOVA test to determine the difference in the amount of pleural fluid at the first, second, and third hours followed by post hoc LSD analysis.

\section{Research Ethic}

This study had received approval for ethical eligibility from Dr. Moewardi Hospital with number 706/V/ HREC/ 2020.

\section{RESULTS}

\section{A. Sample Characteristics}

This study involved 17 subjects with malignant pleural effusions who had WSD insertion, consisting of 10 women and 7 men. This study was grouped based on the outcome of success and failure of pleurodesis procedure, consisting of 11 people succeeded and 6 failed. Characteristic variables that were quantitative with numerical data include age, length of stay, analysis of pleural fluid (LDH, glucose, protein, cell number, mononuclear, and polymorphonuclear), mean of pleural fluid production per day, and amount of pleural fluid drainage in observation 3 times. The first hour, second hour, and third hour were different, as shown in Table 1. Table 2 showed the sample characteristics of the categorical data.

\section{$B$. The result of bivariate analysis}

There was a positive correlation of the amount of pleural fluid and the success rate of pleurodesis in patients with malignant pleural effusion $(r=0.24 ; p=0.345)$. There was a positive correlation of the time of pleurodesis and the success rate of pleurodesis in patients with malignant pleural effusions at three different observation hours; hour I ( $\mathrm{r}=0.10 ; \mathrm{p}=0.701)$, hour II $(\mathrm{r}=0.03 ; \mathrm{p}=0.921)$, and hour III $(\mathrm{r}=0.41$; $\mathrm{p}=0.106)$. These results were shown in Table 3.

Table 4 showed the lowest mean difference in the amount of pleural fluid at hour II of pleurodesis (Mean= 84.66; $\mathrm{SD}=$ 38.88), followed by the hour III (Mean= 110.77; $\mathrm{SD}=65.57)$ and hour I (Mean= 111.22; $\mathrm{SD}=57.83$ ), but it was not statistically significant $(\mathrm{p}=0.285)$.

Post hoc LSD statistical test did not show a significant difference in the amount of pleural fluid between hour I and hour II ( $p=0.168)$, hour I and hour III ( $p=0.981)$, and hour II and hour III $(\mathrm{p}=0.175)$. These results were presented in Table 5. The 
Sutanto et al./ The Relationship of Amount of Pleural Fluid and Time of Pleurodesis

results of this study indicated that there was a tendency for the success of pleuraTable 1. Sample characteristics (continuous data)

\begin{tabular}{lcccc}
\hline \multicolumn{1}{c}{ Variables } & Mean & SD & Min. & Max. \\
\hline Age (years) & 57.82 & 12.486 & 36 & 74 \\
Length of stay (days) & 20.24 & 8.34 & 8 & 34 \\
LDH (mg/ dl) & 924.88 & 1052.25 & 149 & 4202 \\
Glucose (mg/ dl) & 74.71 & 52.19 & 4 & 200 \\
Protein (mg/ dl) & 3.97 & 1.11 & 1.5 & 5.9 \\
Number of cells (/ $\mu \mathrm{l})$ & 968.88 & 885.39 & 170 & 3700 \\
MN (\%) & 51.76 & 30.96 & 3 & 99 \\
PMN (\%) & 54.94 & 68.79 & 1 & 300 \\
Average pleural fluid/day (ml) & & & & \\
Hour I (ml) & 111.22 & 57.83 & 150 & 6400 \\
Hour II (ml) & 84.66 & 38.88 & 400 & 3650 \\
Hour III (ml) & 110.77 & 65.57 & 300 & 8000 \\
\hline
\end{tabular}

Table 2. Sample characteristics (categorical data)

\begin{tabular}{lccc}
\hline Characteristics & Category & n & \% \\
\hline Gender & Male & 10 & $58.80 \%$ \\
Pleurodesis & Female & 7 & $41.20 \%$ \\
Procedure & Failed & 11 & $64.70 \%$ \\
\hline
\end{tabular}

Table 3. The correlation of the total amount of pleural fluid and the time performed pleurodesis with the success rate of pleurodesis in patients with malignant pleural effusion

\begin{tabular}{lcc}
\hline \multicolumn{1}{c}{ Independent Variable } & $\mathbf{r}$ & $\mathbf{p}$ \\
\hline Total amount of pleural fluid & 0.24 & 0.345 \\
Time of pleurodesis & & \\
Hour I & 0.10 & 0.701 \\
Hour II & 0.03 & 0.921 \\
Hour III & 0.41 & 0.106 \\
\hline
\end{tabular}

Table 4. ANOVA test results of the effect of pleurodesis time with the amount of pleural fluid

\begin{tabular}{lccc}
\hline \multicolumn{1}{c}{ Pleura Fluid } & Mean & SD & p \\
\hline Hour I & 111.22 & 57.83 & \\
Hour II & 84.66 & 38.88 & 0.285 \\
our III & 110.77 & 65.57 & \\
\hline
\end{tabular}

Table 5. Post hoc LSD test results of partial comparison of the amount of pleural fluid between pleurodesis time at hour I, II, and III

\begin{tabular}{lcc}
\hline & Comparison & p \\
\hline Hour I vs Hour II & & 0.168 \\
Hour I vs Hour III & 0.981 \\
Hour II vs Hour III & 0.175 \\
\hline
\end{tabular}




\section{DISCUSSION}

This study is the first study to assess the effect of pleurodesis time on the amount of pleural fluid production in the success of pleurodesis. Some studies stated that the amount of pleural fluid production per day before pleurodesis was $<150 \mathrm{ml} /$ day, but it was less relevant for the success of pleurodesis (Roberts et al., 2010). Many recent studies suggested that pleurodesis was more effective when the pleural fluid had been maximally drained, and the lungs were fully expanded as seen from the chest $\mathrm{X}$-ray (Aydin et al., 2009; Yu, 2011). The success of pleurodesis procedure was expected to be able to minimize intrapleural catheter insertion time and shorten the treatment time.

Research conducted by Penz et al. (2017) stated that insertion of a chest tube accompanied by pleurodesis showed unsuccessful pleurodesis in $10-30 \%$ of patients. This was caused by the productive ability of pleural fluid or the evacuation had not been maximal ( $>300 \mathrm{ml} /$ day), trapped lung, and improper location of the chest tube.

There was a tendency for the success of pleurodesis with little pleural fluid between $\mathbf{1 4 . 0 0}$ and 22.00 hours. Comparison of the amount of pleural fluid at the three different times did not show a significant difference in succeed and failed outcomes of pleurodesis. This study showed that there was no relationship between the right time for pleurodesis with the success rate of pleurodesis.

The timing of pleurodesis should be planned when pleural fluid is minimal. There had never been a study evaluating the effectiveness of pleurodesis time on the success rate of pleurodesis, so it was hoped that it could provide a new discourse.

The first limitation of this study was a limited sample size which was collected in a limited time, which was only two months. So, it is better to get better results, making observations on a larger number of samples. Second, after the maximal evacuation of the pleural fluid, chest X-rays evaluation was conducted to assess the expansion of lung, which might prolong the pleurodesis time and affect the success rate of pleurodesis.

\section{AUTHOR CONTRIBUTION}

Authors contributed to the concept, design, analysis, and discussion of data.

\section{CONFLICT OF INTEREST}

This study was self-funded.

\section{FUNDING AND SPONSORSHIP}

There was no conflict of interest in this study.

\section{ACKNOWLEDGEMENT}

We would like to show our gratitude to the Department of Pulmonology and Respiration Medicine, Faculty of Medicine, Sebelas Maret University for their support in this research.

\section{REFERENCE}

Aydin Y, Turkyilmaz A, Intepe YS, Eroglu A (2009). Malignant pleural effusions: appropriate treatment approaches. Eurasian J Med. 41(3): 186-93.

Burgers J, Kunst WA, Koolen MGJ, Willems A, Burgers JS, Heuvel MVD (2008). Pleural drainage and pleurodesis: implementation of guidelines in four hospitals. Eur Respir J, 32(5): 1321-7. doi:10.1183/09031936.00165607.

El-Kolaly RM, Abo-Elnasr M, El-Guindy D (2016). Outcome of pleurodesis using different agents in management of malignant pleural effusion. Egypt $\mathrm{J}$ 
Sutanto et al./ The Relationship of Amount of Pleural Fluid and Time of Pleurodesis

Chest Dis. 65(2): 435-40. doi: 10.1016/j.ejcdt.2015.12.017.

Jantz MA, Antony VB (2008). Pathophysiology of the Pleura. Respiration. 75(2): 121-33. doi: 10.1159/o00113629.

Krochmal R, Reddy C, Yarmus L, Desai NR, Kopman DF, Lee HJ (2016). Patient evaluation for rapid pleurodesis of malignant pleural effusions. J Thorac Dis. 8(9): 2538-43. doi: 10.21037/jtd.2016.08.55.

Penz E, Watt KN, Hergott CA, Rahman NM, Psallidas I (2017). Management of malignant pleural effusion: challenges and solutions. Cancer Manag Res. 9: 229-41. doi: 10.2147/CMAR.S95663.

Rafei H, Jabak S, Mina A, Tfayli A (2015). Pleurodesis in malignant pleural effusions: Outcome and predictors of success. Integr Cancer Sci Ther. 2(5): 216-21. doi: 10.15761/icst.1000144.
Roberts ME, Neville E, Berrisford RG, Antunes G, Ali NJ (2010). Management of a malignant pleural effusion: British Thoracic Society pleural disease guideline 2010. Thorax. 65(2): II32-40. doi: 10.1136/thx.2010.-136994.

Shafiq M, Kopman DF (2015). Management of malignant pleural effusions. J Bronchology Interv Pulmonol. 22(3): 215-25. doi: 10.1097/LBR.ooooooo000000192.

Liu C, Qian Q, Geng S, Sun W, Shi Y (2015). Palliative treatment of malignant pleural effusion. Cancer Transl Med. 1(4): 131. doi: 10.4103/2395-3977.163804 .

$\mathrm{Yu} \mathrm{H}$ (2011). Management of pleural effusion, empyema, and lung abscess. Semin Intervent Radiol. 28(1): 75-86. doi: 10.1055/s-0031-1273942. 